(c) American Dairy Science Association, 2003.

\title{
Technical Note: DNA Typing for Ovine MHC DRB1 Using Polymerase Chain Reaction-Restriction Fragment Length Polymorphism (PCR-RFLP)
}

\author{
S. Konnai, ${ }^{*}{ }^{,}{ }^{, 1}$ Y. Nagaoka, ${ }^{*, 1,2}$ S. Takesima, ${ }^{*}$ M. Onuma, $\dagger$ and Y. Aida ${ }^{*}$ \\ *Retrovirus Research Unit, RIKEN, 2-1 Hirosawa, \\ Wako, Saitama 351-0198 Japan \\ †Department of Disease Control, Graduate School of Veterinary Medicine, \\ Hokkaido University, Sapporo, Hokkaido 060-0818 Japan
}

\begin{abstract}
The ovine major histocompatibilty complex (Ovar) class II $D R B 1$ second exon was amplified by polymerase chain reaction (PCR) from DNA samples of 52 Suffolk sheep. Polymerase chain reaction products were characterized by the restriction fragment length polymorphism (RFLP) technique using nine restriction enzymes, RsaI, HaeIII, SacI, SacII, DdeI, NciI, Hin1I, $E c o R \mathrm{I}$, and Bst NI, yielding 13 types. Sequencing of cloned PCR products identified 16 Ovar-DRB1 alleles. Collectively, all PCR-RFLP patterns exactly matched those predicted from DNA sequences. These findings strongly indicate that the PCR-RFLP method using a combination of nine restriction endonucleases is a very powerful tool in Ovar typing.
\end{abstract}

(Key words: Ovar-DRB1 exon 2, PCR-RFLP, genetic polymorphism, restriction enzyme)

Abbreviation key: $\mathbf{M H C}=$ major histocompatibility complex, Ovar = ovine MHC, SSCP $=$ single-strand conformational polymorphism.

The major histocompatibility complex (MHC) of sheep is known as Ovar and is located on chromosome 20 . The Ovar class II genes encode polymorphic glycoproteins composed of noncovalently linked $\alpha$ - and $\beta$ subunits that play a pivotal role in the initiation of the immune response to pathogen-derived peptide antigens. Among Ovar MHC class II genes, the expressed $D R B 1$ locus has been found to be highly polymorphic. To date, 106 Ovar-DRB1 alleles have been identified by DNA sequencing of exon 2 from various breeds of

Received March 6, 2003.

Accepted May 14, 2003.

Corresponding author: Y. Aida; e-mail: aida@postman.riken.go.jp.

${ }^{1}$ The first two authors contributed equally to the report.

${ }^{2}$ Present address: Y. Nagaoka, Brain Research Institute, RIKEN, 2-1Hirosawa, Wako, Saitama 251-0198, Japan. sheep (Ballingall et al., 1992; Fabb et al., 1993; Schwaiger et al., 1994; Ballingall et al., 1995; Schwaiger et al., 1995; Kostia et al., 1998; Paterson 1998; Nagaoka et al., 1999; Jugo and Vicario, 2000; Konnai et al., 2003; GenBank, accession numbers: M73984, Z92726 to Z92735, AF324840 to AF324861).

In studies of variation in disease susceptibility, it is important to have the ability to characterize MHC polymorphism and determine its relationship to immune responsiveness. This requires reliable and sensitive typing methods. Several methods are now available to analyze MHC polymorphism in domestic animals. In sheep, the polymorphism of Ovar-DRB1 has been defined using several PCR-based methods including sequence-specific oligonucleotide probe analysis (Schwaiger et al., 1993; and Schwaiger et al., 1994), single-strand conformational polymorphism (SSCP) (Kostia et al., 1998; Jugo and Vicario, 2000), RFLP analysis with identification using Southern blot analysis (Dutia et al., 1994) and cloning and sequencing (Nagaoka et al., 1999). On the other hand, in other domestic species, such as the cow (van Eijk et al., 1992), goat (Amills et al., 1996), pig (Shia et al., 1995), dog (Francino et al., 1997), cat (Kuwahara et al., 2000), and mouse (Peng and Craft, 1996), PCR-RFLP provides a simple method for the rapid analysis of class II polymorphisms. However, there is very little information available about PCR-RFLP methods for Ovar typing. Here, we describe the development of PCRRFLP method that allows identification of polymorphisms in exon 2 of Ovar-DRB1 for large numbers of animals and discuss the relationship between the results of PCR-RFLP and the identification of Ovar$D R B 1$ alleles determined by cloning and sequencing of genomic DNA.

To develop the PCR-RFLP method, we received blood samples from 52 1-yr-old Suffolk sheep donated from JAPAN LAMB Co., Ltd., and two associated farms, Hiroshima farm and Otofuke farm. Samples of genomic DNA were obtained from whole blood as described by Takeshima et al. (2001, 2002). The second exon of Ovar- 
$D R B 1$ was amplified by PCR technique in two stages because it was difficult to amplify the alleles from all samples by a single PCR. Therefore, to avoid mistakes due to PCR errors, we amplified alleles from five separate PCR per animal and confirmed whether these sequences were identical among five clones. The first round of PCR was performed with primers OLA-ERB1 (GC) 5'-CCG GAA TTC CCG TCT CTG CAG CAC ATT TCT T-3' and HL031 5'-TTT AAA TTC GCG CTC ACC TCG CCG CT-3' (van Eijk et al., 1992). We subjected $100 \mathrm{ng}$ of genomic DNA to amplification by PCR in a total volume of $20 \mu \mathrm{l}$ of PCR buffer [10 $\mathrm{mM}$ Tris-HCl (pH 8.3), $50 \mathrm{~m} M \mathrm{KCl}, 0.1 \%$ Triton X 100, $1.5 \mathrm{~m} M \mathrm{MgCl}_{2}$, and $120 \mu M \mathrm{dNTP}$, to which $0.2 \mathrm{~m} M$ each primer, and 2.5 U of rTaq polymerase (Toyobo Biochemicals, Tokyo, Japan) had been added. Reactions were performed in a thermocycler (TGRADIENT 96; Biometra, Goettingen, Germany) under the following conditions: one cycle of incubation for $5 \mathrm{~min}$ at $94^{\circ} \mathrm{C}$, followed by 15 cycles of $94^{\circ} \mathrm{C}$ for $30 \mathrm{~s}, 50^{\circ} \mathrm{C}$ for $30 \mathrm{~s}$, and $72^{\circ} \mathrm{C}$ for $60 \mathrm{~s}$, with final extension at $72^{\circ} \mathrm{C}$ for $10 \mathrm{~min}$. We used $3 \mu \mathrm{l}$ of the resulting mixture, plus primers OLA-ERB1 (GC) and OLA-XRBI (5'-AGC TCG AGC GCT GCA CAG TGA $\mathrm{AAC}$ TC-3') for the second round of PCR. The conditions for the second round of PCR were one cycle for $5 \mathrm{~min}$ at $94^{\circ} \mathrm{C}$, followed by 30 cycles of $94^{\circ} \mathrm{C}$ for $30 \mathrm{~s}, 60^{\circ} \mathrm{C}$ for $30 \mathrm{~s}$, and $72^{\circ} \mathrm{C}$ for $60 \mathrm{~s}$ with final extension at $72^{\circ} \mathrm{C}$ for $10 \mathrm{~min}$. Ten microliters of the mixture after the second round of $\mathrm{PCR}$ were digested for $4 \mathrm{~h}$ at $37^{\circ} \mathrm{C}$ with $5 \mathrm{U}$ of RsaI (Toyobo Biochemicals), HaeIII (Toyobo Biochemicals), SacI (Toyobo Biochemicals), SacII (Toyobo Biochemicals), DdeI (New England Biolabs Inc., Beverly, MA), NciI (New England Biolabs Inc.), Hin1I (Takara Biomedicals, Otsu, Japan), EcoRI (Toyobo Biochemicals) or at $60^{\circ} \mathrm{C}$ with $5 \mathrm{U}$ of BstNI (New England Biolabs Inc.) in a total volume of $20 \mu \mathrm{l}$. Samples were resolved by a 3 or $5 \%$ agarose gel electrophoresis.

When each amplified product was cleaved by the restriction enzymes, we observed the following numbers of patterns in each of the digests: RsaI, 8; HaeIII, 6; SacI, 2; SacII, 2; DdeI, 3; NciI, 2; Hin1I, 2; EcoRI, 2; and BstNI, 2 (Table 1). Collectively, using PCR-RFLP, 13 Ovar-DRB1 PCR-RFLP types (01-13) were identified in 52 Suffolk sheep. Examples of the PCR-RFLP analysis are shown in Figure 1. We verified the predicted RFLP profiles of Ovar-DRB1 alleles by sequencing cloned amplified products as described elsewhere $(\mathrm{Na}-$ gaoka et al., 1999), and all the observed patterns of fragments matched exactly those predicted from DNA sequences (Figure 2). Sequencing of cloned PCR allowed the identification of 16 Ovar-DRB1 alleles among the 52 animals. These findings indicate that PCR-RFLP with nine restriction enzymes is a very powerful tool for Ovar typing.

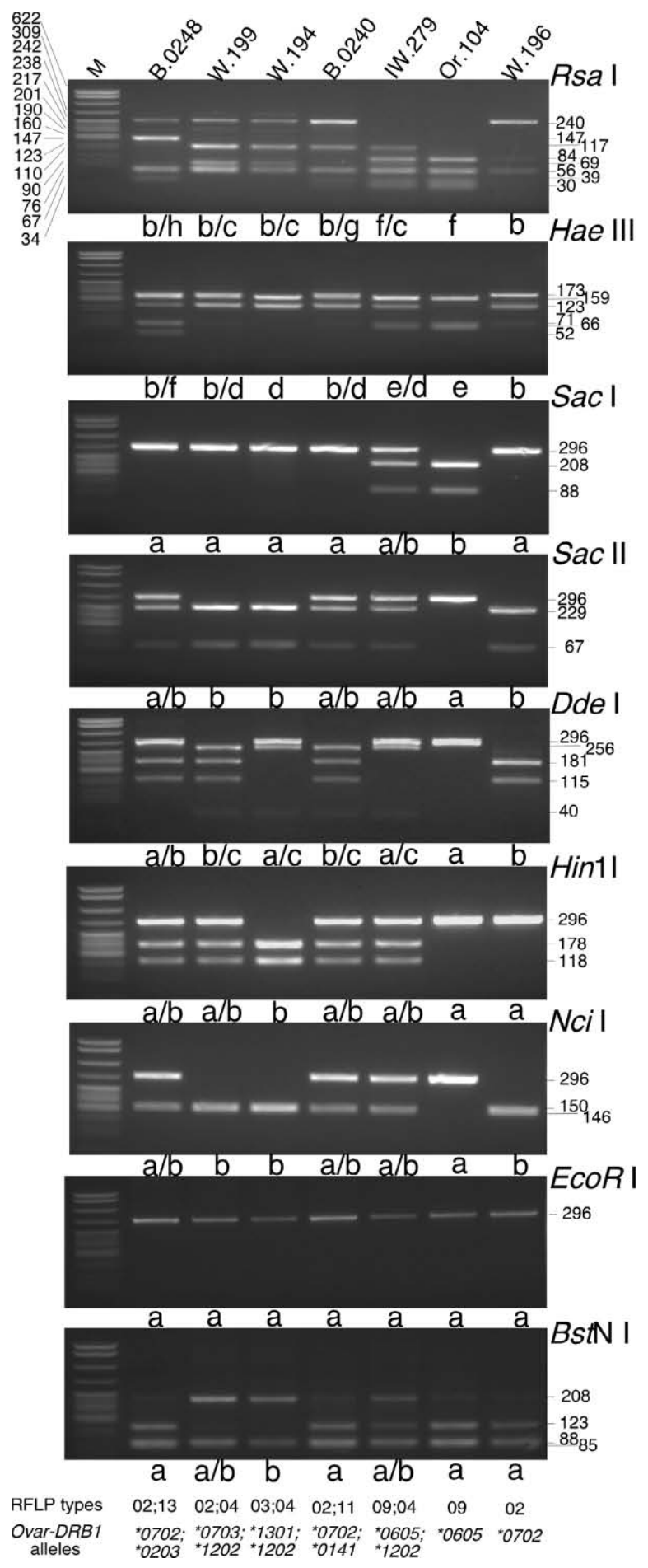

Figure 1. The PCR-RFLP analysis of exon 2 of the Ovar-DRB1 gene (296 bp) from seven Suffolk sheep, B.0248, W.199, W194, B.0240, IW.279, Or.104, and W.196. The PCR-amplified fragments of DNA from the second-round of PCR were cleaved by RsaI, HaeIII, SacI, SacII, DdeI, NciI, Hin1I, EcoRI, and BstNI. M is MspI digest of pBR322 DNA fragment size marker. Two animals, Or.104 and W.196, each yield a single pattern with all nine restriction enzymes (homozygosity), while five animals, namely, B.0248, W.199, W194, B.0240, and IW.279, yielded multiple heterozygous patterns. 
Table 1. Definition of 16 ovine major histocompatibility complex class II exon 2 alleles by PCR-RFLP using nine restriction enzymes.

\begin{tabular}{lllllllllll}
\hline \multirow{2}{*}{$\begin{array}{l}\text { PCR-RFLP } \\
\text { types }\end{array}$} & RsaI & HaeIII & SacI & SacII & DdeI & Hin $1 \mathrm{I}$ & NciI & EcoRI & BstNI & Ovar-DRB1 alleles \\
\cline { 2 - 8 } 01 & $\mathrm{a}$ & $\mathrm{a}$ & $\mathrm{a}$ & $\mathrm{a}$ & $\mathrm{b}$ & $\mathrm{a}$ & $\mathrm{a}$ & $\mathrm{a}$ & $\mathrm{a}$ & $* 0801$ \\
02 & $\mathrm{~b}$ & $\mathrm{~b}$ & $\mathrm{a}$ & $\mathrm{b}$ & $\mathrm{b}$ & $\mathrm{a}$ & $\mathrm{b}$ & $\mathrm{a}$ & $\mathrm{a}$ & $* 0702, * 0703$ \\
03 & $\mathrm{~b}$ & $\mathrm{~d}$ & $\mathrm{a}$ & $\mathrm{b}$ & $\mathrm{a}$ & $\mathrm{b}$ & $\mathrm{b}$ & $\mathrm{a}$ & $\mathrm{b}$ & $* 1301$ \\
04 & $\mathrm{c}$ & $\mathrm{d}$ & $\mathrm{a}$ & $\mathrm{b}$ & $\mathrm{c}$ & $\mathrm{b}$ & $\mathrm{b}$ & $\mathrm{a}$ & $\mathrm{b}$ & $* 1202$ \\
05 & $\mathrm{c}$ & $\mathrm{f}$ & $\mathrm{a}$ & $\mathrm{a}$ & $\mathrm{a}$ & $\mathrm{a}$ & $\mathrm{b}$ & $\mathrm{a}$ & $\mathrm{a}$ & $* 03411$ \\
06 & $\mathrm{~d}$ & $\mathrm{c}$ & $\mathrm{b}$ & $\mathrm{a}$ & $\mathrm{a}$ & $\mathrm{a}$ & $\mathrm{b}$ & $\mathrm{b}$ & $\mathrm{a}$ & $* 03012$ \\
07 & $\mathrm{e}$ & $\mathrm{e}$ & $\mathrm{a}$ & $\mathrm{a}$ & $\mathrm{a}$ & $\mathrm{a}$ & $\mathrm{b}$ & $\mathrm{a}$ & $\mathrm{a}$ & $* 0332$ \\
08 & $\mathrm{f}$ & $\mathrm{e}$ & $\mathrm{a}$ & $\mathrm{a}$ & $\mathrm{a}$ & $\mathrm{a}$ & $\mathrm{a}$ & $\mathrm{a}$ & $\mathrm{a}$ & $* 0323, * 0333$ \\
09 & $\mathrm{f}$ & $\mathrm{e}$ & $\mathrm{b}$ & $\mathrm{a}$ & $\mathrm{a}$ & $\mathrm{a}$ & $\mathrm{a}$ & $\mathrm{a}$ & $\mathrm{a}$ & $* 0605$ \\
10 & $\mathrm{f}$ & $\mathrm{f}$ & $\mathrm{b}$ & $\mathrm{a}$ & $\mathrm{c}$ & $\mathrm{b}$ & $\mathrm{a}$ & $\mathrm{a}$ & $\mathrm{a}$ & $* 0109$ \\
11 & $\mathrm{~g}$ & $\mathrm{~d}$ & $\mathrm{a}$ & $\mathrm{a}$ & $\mathrm{c}$ & $\mathrm{b}$ & $\mathrm{a}$ & $\mathrm{a}$ & $\mathrm{a}$ & $* 01072, * 0141$ \\
12 & $\mathrm{~g}$ & $\mathrm{~d}$ & $\mathrm{a}$ & $\mathrm{a}$ & $\mathrm{a}$ & $\mathrm{b}$ & $\mathrm{a}$ & $\mathrm{a}$ & $\mathrm{a}$ & $* 0201$ \\
13 & $\mathrm{~h}$ & $\mathrm{f}$ & $\mathrm{a}$ & $\mathrm{a}$ & $\mathrm{a}$ & $\mathrm{b}$ & $\mathrm{a}$ & $\mathrm{a}$ & $\mathrm{a}$ & $* 0203$ \\
\hline
\end{tabular}

In cattle, 56 of the 106 sequenced $\mathrm{MHC}$ (BoLA)-DRB3 alleles from exon 2 could be distinguished as 56 PCRRFLP types (http//www.projects.roslin.ac.uk/bola/bolafram.html). Moreover, using PCR-RFLP typing, many new BoLA-DRB3.2 allele types were found in Jersey cows, European cattle, and African cattle that have not been reported previously (Gelhous et al., 1995; Gillisepie et al., 1998). We also investigated the predicted RFLP patterns in 106 previously described Ovar-DRB1 alleles using our system. Furthermore, the 106 se- quenced Ovar-DRB1 alleles could be distinguished as 63 restriction fragment patterns by PCR-RFLP (data not shown). Thus, PCR-RFLP typing may be useful for the characterization of polymorphism in exon 2 of the Ovar-DRB1 gene as well as for PCR-RFLP typing for BoLA-DRB3.2 alleles. On the other hand, in this study, we have not yet verified the PCR-RFLP patterns of many Ovar-DRB1 alleles. It should, however, be emphasized that the predicted PCR-RFLP patterns of endonucleases used have been individually verified, be-

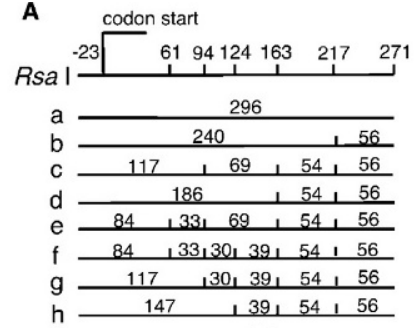

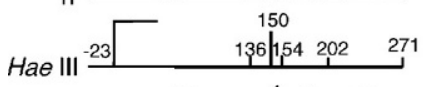
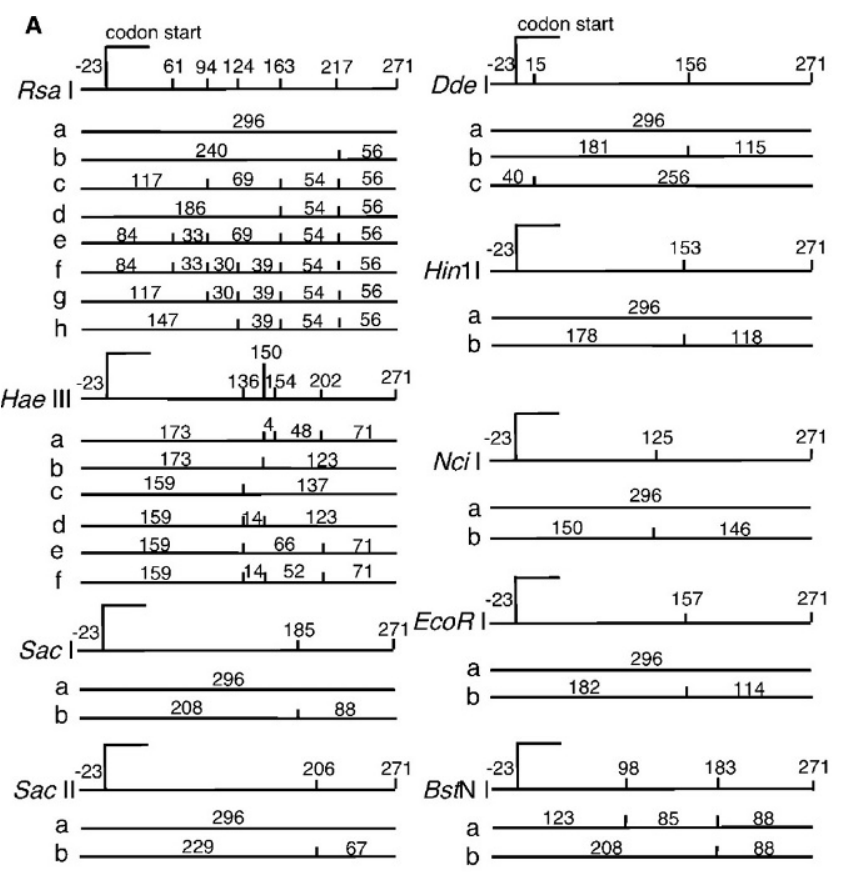

B

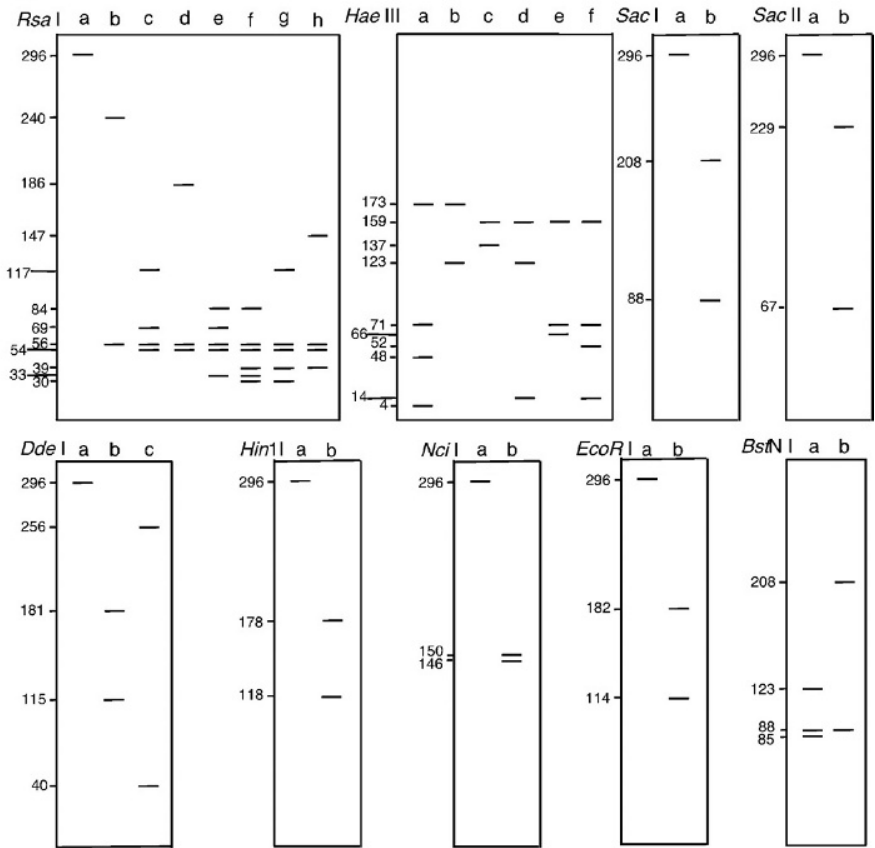

Figure 2. The RFLP patterns (A) and sizes (B) of Ovar-DRB1 alleles exon 2 with the enzymes RsaI, HaeIII, SacI, SacII, DdeI, Hin1I, NciI, EcoRI, and BstNI. The full length of the second-round products of PCR for alleles without a deletion is $296 \mathrm{bp}(237+59 \mathrm{bp})$. Numbers indicate the sizes of DNA fragments in base pairs. 
cause in this study all the observed PCR-RFLP patterns of fragments matched exactly those predicted from DNA sequences. The reliability and sensitivity of the PCR-RFLP method is attributed to strict enzyme substrate specificity of endonucleases that can reproducibly resolve a one-base mismatch in sequence. Thus, based on the published exon 2 sequences, we anticipate that our chosen panel of endonucleases will yield the predicted PCR-RFLP profiles for as yet unverified Ovar$D R B 1$ alleles.

In sheep, the polymorphism of Ovar-DRB1 has been defined by PCR-sequence-specific oligonucleotide probe analysis (Schwaiger et al., 1993; Schwaiger et al., 1994) and PCR-SSCP (Kostia et al., 1998; Jugo and Vicario, 2000), and these methods are relatively more time-consuming and expensive than the PCR-RFLP method. Furthermore, this method enables us to establish a molecular typing method for identifying Ovar-DRB1 polymorphisms in large cohorts of animals, and the PCR-RFLP method might be a useful tool for analysis of frequencies of alleles in sheep. Therefore, the PCRRFLP method may be used either independently or to complement Ovar-DRB1 typing by PCR-SSO and PCRSSCP methods in order to define or confirm allele identity.

\section{ACKNOWLEDGMENTS}

This work was supported by grants-in-Aid for Scientific Research (A) and (B) from the Japan Society for the Promotion of Science (JSPS), and by a special grant for the promotion of research from RIKEN.

\section{REFERENCES}

Amills, M., O. Francino, and A. Sanchez. 1996. A PCR-RFLP typing method for the caprine MHC class II DRB gene. Vet. Immunol. Immunopahol. 55:255-260.

Ballingall, K. T., H. Wright, J. Redmond, B. M. Dutia, J. Hopkins, J. Lang, E. V. Deverson, J. C. Howard, N. Puri, and D. Haig. 1992. Expression and characterization of ovine major histocompatibility complex class II (OLA-DR) genes. Anim. Genet. 23:347-359.

Ballingall, K. T., B. M. Dutia, J. Hopkins, and H. Wright. 1995. Analysis of the fine specificities of sheep major histocompatibility complex class II-specific monoclonal antibodies using mouse Lcell transfectants. Anim. Genet. 26:79-84.

Dutia, B. M., I. McConnell, K. T. Ballingall, P. Keating, and J. Hopkins. 1994. Evidence for the expression of two distinct MHC class II DR beta like molecules in the sheep. Anim. Genet. 25:235-241.

Fabb, S. A., J. F. Maddox, K. J. Gogolin-Ewens, L. Baker, M. J. $\mathrm{Wu}$, and M. R. Brandon. 1993. Isolation, characterization and evolution of ovine major histocompatibility complex class II DRA and DQA genes. Anim. Genet. 24:249-255.

Francino, O., M. Amills, and A. Sanchez. 1997. Canine MHC DRB1 genotyping by PCR-RFLP analysis. Anim. Genet. 28:41-45.

Gelhaus A., L. Schnittger, D. Mehlitz, R. D. Horstmann, and C. G. Meyer. 1995. Sequence and PCR-RFLP analysis of 14 novel BoLADRB3 alleles in Jersey cows. Anim. Genet. 26:147-153.

Gilliespie, B. E., B. M. Jayarao, H. H. Dowlen, and S. P. Oliver. 1999. Analysis and frequency of bovine lymphocyte antigen DRB3.2 alleles in Jersey cows. J. Dairy Sci. 82:2049-2053.

Jugo, B. M., and A. Vicario. 2000. Single-strand conformational polymorphism and sequence polymorphism of MHC-DRB in Latxa and Karrantzar sheep: Implications for Caprinae phylogeny. Immunogenetics 51:887-897.

Konnai, S., Y. Nagaoka, S. Takeshima, M. Onuma, and Y. Aida. 2003. Sequences and diversity of 17 new Ovar-DRB1 alleles from three breeds of sheep. Eur. J. Immunogenet. 30:275-282.

Kostia, S., J. Kantanen, M. Kolkkala, and S. L. Varvio. 1998. Applicability of SSCP analysis for MHC genotyping: fingerprinting of Ovar-DRB1 exon 2 alleles from Finnish and Russian breeds. Anim. Genet. 29:453-455.

Kuwahara, Y., K. Kitoh, R. Kobayashi, J. Iwata, R. Ohne, T. Hosokawa-Kanai, Y. Matsumoto, H. Kitagawa, and Y. Sasaki. 2000. Genotyping of feline MHC (FLA) class II DRB by PCR-RFLP method using group-specific primers. J. Vet. Med. Sci. 62:1283-1289.

Mahdy, E. A., A. Makinen, B. P. Chowdhary, L. Andersson, and I. Gustavsson. 1989. Chromosomal localization of the ovine major histocompatibility complex (OLA) by in situ hybridization. Hereditas 111:87-90.

Nagaoka, Y., H. Kabeya, M. Onuma, N. Kasai, K. Okada, and Y. Aida. 1999. Ovine MHC class II DRB1 alleles associated with resistance or susceptibility to development of bovine leukemia virus-induced ovine lymphoma. Cancer Res. 59:975-981.

Paterson, S. 1998. Evidence for balancing selection at the major histocompatibility complex in a free-living ruminant. J. Hered. 89:289-294.

Peng, S. L., and J. Craft. 1996. PCR-RFLP genotyping of murine MHC haplotypes. Biotechniques 362:366-368.

Schwaiger, F. W., J. Buitkamp, E. Weyers, and J. T. Epplen. 1993. Typing of artiodactyl MHC-DRB genes with the help of intronic simple repeated DNA sequences. Mol. Ecol. 2:55-59.

Schwaiger, F. W., E. Weyers, J. Buitkamp, A. J. Ede, A., Crawford, and J. T. Epplen. 1994. Interdependent MHC-DRB exon-plusintron evolution in artiodactyls. Mol. Biol. Evol. 11:239-249.

Schwaiger, F. W., D. Gostomski, M. J. Stear, J. L. Duncan, Q. A. Mckellar, J. T. Epplen, and J. Buitkamp. 1995. An ovine major histocompatibility complex DRB1 allele is associated with low faecal egg counts following natural predominantly Ostertagia circumcincta infection. Int. J. Parasitol. 25:815-822.

Shia, Y. C., M. Bradshaw, M. S. Rutherford, H. A. Lewin, and L. B. Schook. 1995. Polymerase chain reaction based genotyping for characterization of SLA-DQB and SLA-DRB alleles in domestic pigs. Anim. Genet. 26:91-100.

Takeshima, S., M. Ikegami, M. Morita, Y. Nakai, and Y. Aida. 2001. Identification of new cattle BoLA-DRB3 alleles by sequence-based typing. Immunogenetics 53:74-81.

Takeshima, S., Y. Nakai, M. Ohta, and Y. Aida. 2002. Characterization of DRB3 alleles in the MHC of Japanese Shorthorn cattle by polymerase chain reaction-sequence-based typing. J. Dairy Sci. 85:1630-1632.

van Eijk, M. J., J. A. Stewart-Haynes, and H. A. Lewin. 1992. Extensive polymorphism of the BoLA-DRB3 gene distinguished by PCRRFLP. Anim. Genet. 23:483-496. 